\title{
Nutritional quality of formulated complementary diet from defatted almond seed, yellow maize and quality protein maize flours
}

\author{
Ade Raymond Adesanmi ${ }^{1}$, Sunday Abiodun Malomo ${ }^{2 *}$ and Tayo Nathaniel Fagbemi ${ }^{2}$
}

\begin{abstract}
Traditional complementary foods are mainly starchy foods with limiting nutrient quality and can be fortified using protein rich crops like almond seed. This research thus aimed at investigating the nutritional quality of the formulated complementary diet from locally available almond seeds (Prunus amygdalus), high quality protein (QPM) and yellow maize after blending into flours. The proximate and amino acid compositions, in vitro protein qualities and functional properties of the blended flours were determined using standard methods. The in vivo studies involved feeding the weanling Wister albino rats with blended flours and commercial Cerelac (control), followed by hematological and histopathological determinations, while sensory attributes were evaluated by the semi-trained panelists. The protein contents of the flour blends (24-28\%) were significantly $(p<0.05)$ better with adequate indispensable amino acids and improved functionalities than commercial cerelac (23\%). Comparatively, the dried germinated QPM (DGQPM) has significant $(p<0.05)$ higher biological value $(\sim 37 \%)$ than fermented high QPM (FHQPM) ( 30\%), thereby indicating that the germination process improved protein quality of the diets. Besides, the in vivo data showed a positive effect of germination process as the rats fed with DGQPM has low white blood cells $\left(30 \times 10^{2}\right)$ compared to FHQPM $\left(42 \times 10^{2}\right)$ and cerelac $\left(51 \times 10^{2}\right)$. However, the fermentation process improved the packed cell volume of rats fed with FHQPM (49\%) when compared to DGQPM and cerelac (47\%). The formulated diets have no negative effects on the protein content $(45.19-51.88 \mathrm{mg} \mathrm{N} / \mathrm{g})$ and weight $(0.25-1.36 \mathrm{~g})$ of the internal organs (liver, kidney and tissue) of the animals when compared to cerelac (53.72-55.04 mg N/g; 0.25$1.98 \mathrm{~g}$ ), respectively. The panelists generally accepted all the formulated diets, hence encouraging their utilization in the global preparation of complimentary foods for young children to meet their nutritional needs and adding value to the locally produced underutilized almond seeds.
\end{abstract}

Keywords: Quality protein, Yellow maize, Almond seed, Nutrient composition, Complementary

\section{Introduction}

An adequate nutrition within the first 1000 days has been reported to be essential for healthy growth and development in children for their full potential (Motuma et al. 2016). The consequences of poor nutrition include

\footnotetext{
* Correspondence: samalomo@futa.edu.ng

${ }^{2}$ Department of Food Science and Technology, Federal University of

Technology, Akure, Nigeria

Full list of author information is available at the end of the article
}

illness such as common childhood diarrhea, global malnutrition (Onyango et al. 2014), stunting (a state of an adult being shorter than potential height), and micronutrient deficiencies (Motuma et al. 2016). Therefore, the introduction of protein and energy-rich complementary foods to the children is very critical at this stage in order to avert the challenges of good nutrition faced by the children of 6-23 months in most developing countries (Udoh and Amodu 2016). Besides, highly nutritious diets

(c) The Author(s). 2020 Open Access This article is licensed under a Creative Commons Attribution 4.0 International License, which permits use, sharing, adaptation, distribution and reproduction in any medium or format, as long as you give appropriate credit to the original author(s) and the source, provide a link to the Creative Commons licence, and indicate if changes were made. The images or other third party material in this article are included in the article's Creative Commons licence, unless indicated otherwise in a credit line to the material. If material is not included in the article's Creative Commons licence and your intended use is not permitted by statutory regulation or exceeds the permitted use, you will need to obtain permission directly from the copyright holder. To view a copy of this licence, visit http://creativecommons.org/licenses/by/4.0/. 
with rich amino acid contents, such as arginine, tyrosine/phenylalanine and valine/leucine, have the capacity of fighting against the chronic cardiovascular diseases. For instance, arginine, aromatic and branched-chain amino acids have been extensively reported for their health beneficial effects such as, antioxidant (Malomo et al. 2020), antihypertensive (Poggiogalle et al. 2019) and adequate combating agents towards protein-energy malnutrition commonly associated with growing children (Arise et al. 2020).

Over a very long period of time in the developing countries, cereal based complementary food often fail to meet the nutritional need of younger children due to poor/low nutrient contents (Ijarotimi and Keshinro 2012a). Such cereals like sorghum, rice and maize constituted about $85 \%$ of total global cereals utilized in preparation of local complementary foods (Sofi et al. 2009) but with implications of having low protein contents (Tufa et al. 2016). However, some average-income earners nowadays prepare their complementary foods from cereals mixed with roasted soybeans and crayfish flours (Alamu et al. 2018). This practice might be very expensive for most low-income earners or the rural dwellers but who could find the locally available and underutilized almond seeds useful for their own preparation.

Almond seeds contain about $21.2 \%$ protein with $30 \mathrm{~g}$ serving of almonds providing $6.3 \mathrm{~g}$ of protein (Ahren et al. 2005; United States Department of Agriculture, USDA 2018) with lots of phytosterols and ranked number two after cashew nuts in tree nut (Shakerardekani et al. 2013). Studies had shown that besides high nutritive values, almonds provide varied healthful effects like cardiometabolic, modulation of blood glucose fluctuations, reduction in postprandial plasma lipids and free radicals scavengers (Tan and Mattes 2013; Esquius et al. 2020; Palacios et al. 2020; Semidei et al. 2020).

Quality protein maize (QPM) is a bio-fortified maize with higher amount (46 and 66\% higher than common maize) of lysine and tryptophan (the first and second limiting amino acids in common maize), respectively (Ikujenlola and Ogunba 2018) but lower amount of leucine and isoleucine (Fagbemi et al. 2018). These two amino acids (lysine and tryptophan) are found indispensable for healthy growth and developments of infants and young children (Ijarotimi and Keshinro 2012a). Such a balanced combination of amino acids in the endosperm resulted into its higher biological value ensuring more availability of protein to human being than common maize (Ikujenlola and Ogunba 2018). Although, the total amount of protein in QPM is not actually increased but the protein is enhanced so that it delivered a higher benefit when consumed by human beings (Fagbemi et al. 2018). QPM has previously been used to produce breakfast and weaning food blends (Abiose and Ikujenlola 2014; Ikujenlola and Ogunba 2018; Krishna-Motukuri 2019; Gemede 2020; Parsons et al. 2020).

The nutritional problems arising from wide utilization of common maize, sorghum and guinea corn with poor/ low protein contents, limiting lysine and tryptophan as well as expensive purchasing cost of high protein sources (Ikujenlola and Ogunba 2018) had paved way for the utilization of almond seeds and QPM. Therefore, there is need to explore the nutritional qualities of these crops in the production of complementary food for children due to their nutrient composition and accessibility to many low-income homes. Besides, the germination of QPM has the advantage of breaking down the complex sugars and other matrix of the nutrients available within the QPM, to make more protein and amino acids available (Mares et al. 2018), while fermentation caused the reduction of these organic portions through the increase in the metabolic activities of the microbes (Olagunju and Ifesan 2013).

Although, significant information abound globally on the use of composite flour blends from different cereal and legume crops but there exist scanty information on the utilization of almond seed and QPM blends as complementary food for children. Hence, the aim of this study was to formulate and assess the nutritional quality of almond seed, QPM and yellow maize flour blends as ingredients for complementary food.

\section{Materials and methods Materials}

The almond fruits (Prunus amygdalus) were collected fresh from the Federal Polytechnic, Ado-Ekiti, Ekiti State, Nigeria. High quality protein and yellow maize were purchased from Institute of Agricultural Research and Training, Moor Plantation, Apata Ganga, Ibadan, Oyo State, Nigeria. The weanling Wister albino rats (150-185 g) were purchased from Department of Biochemistry, Obafemi Awolowo University, Ile-Ife, Osun State, Nigeria. N-hexane, other chemicals and reagents used were purchased from Rovet Stores, Akure, Ondo State, Nigeria. The Cerelac (a commercial product) and basal diet (both control samples) were obtained from NAO supermarket, Akure, Ondo State, Nigeria.

\section{Processing of de-fatted almond seed to flour}

The almond seeds were defatted and processed into flour using the method previously described by Tan and Mattes (2013). The edible portion of the fruit was manually removed leaving the stony shell containing the seed. The stony shell was carefully cracked using harmer to remove the nut. The almond (nuts) were sorted and dried in hot air oven at $60^{\circ} \mathrm{C}$ until dried, and then milled, using a Philips laboratory blender (Philips 
HR2811 model, Amsterdam, Netherland). The resulting meal was defatted using $n$-hexane in a soxhlet extraction apparatus as described by AOAC (2005). The defatted sample was air-dried in a fume hood at room temperature to drive off the $n$-hexane completely, the flour was blended by using a blender and thereafter sieved and preserved in tightly closed plastic container pending analysis.

\section{Processing of maize into fermented and germinated maize flours}

The fermented maize flour was prepared according to the method previously described by Ijarotimi and Keshinro (2012b) with slight modification. The maize grains were cleaned sorted and steeped in water for $72 \mathrm{~h}$ to naturally ferment. The steep water was decanted and the maize was washed in clean water after which they were wet-milled using hammer mill. After milling, the slurry was sieved with cheese-cloth and the coarse particle was discarded and the slurry was settled for $3 \mathrm{~h}$. The washed water was decanted, the sediment was transferred into a clean cheese-cloth and pressed to remove excess water by using locally manufactured hydraulic press. The sediment was dried in an air oven at $50{ }^{\circ} \mathrm{C}$ for $48 \mathrm{~h}$ and re-milled into fine flour and stored in air-tight plastic container in a cool dry place for further analysis and formulation.

The germinated maize flour was obtained according to the method previously described by Ijarotimi and Keshinro (2012a). Briefly, the maize grains were soaked in water for $2 \mathrm{~h}$ to achieve hydration, after which it was then left at room temperature $\left(25^{\circ} \mathrm{C}\right)$ for $48 \mathrm{~h}$. This was thereafter rinsed and spread on a jute bag for germination to take place while the seeds were closely monitored, frequently watered and separated so as to prevent mold growth. After $48 \mathrm{~h}$ the seeds were rinsed and the germination process was terminated by exposing the seeds to a temperature of $40{ }^{\circ} \mathrm{C}$ for $5 \mathrm{~h}$. The germinated seeds were milled into flour using hammer mill and then sieved through a $0.4 \mathrm{~mm}$ mesh size, packaged in highdensity polyethylene bag and stored in a refrigerator at $4{ }^{\circ} \mathrm{C}$ till further use.

\section{Formulation of the complementary diets}

The complementary diets were made from blends of $70 \%$ maize (QPM or yellow maize) and 30\% defatted almond flour as previously described by Ijarotimi and Keshinro (2012a). The mixes obtained were thoroughly blended together using Philips laboratory blender (Philips HR2811 model, Amsterdam, Netherland). After blending, the blend mixes were packed and sealed in high-density polythene bags until required while cerelac was used as a control.

\section{Proximate composition analysis}

The proximate analysis (moisture, protein, fat, ash and crude fiber) of the diets was determined according to the methods of Association of Official Analytical Chemists (AOAC 2005) while the carbohydrate content was calculated by difference. The crude protein and fat contents were obtained by micro-Kjedahl $(\mathrm{N} \times 6.25)$ and soxhlet procedures, respectively.

\section{Amino acid composition analysis}

Amino acid content was determined using Pico-Tag method as previously described by Bidlingmeyer et al. (1984). The cysteine and methionine (sulphur-containing amino acids) were determined after performic acid oxidation as described by Gehrke et al. (1985) and tryptophan was determined after alkaline hydrolysis as described by Landry and Delhaye (1992). Briefly, sample was hydrolysed, evaporated in a rotary evaporator and loaded into Technicon Sequential Multi-Sample Amino Acid Analyser (TSM-1) (Technicon Instruments Corporation, New York, USA). $10 \mu \mathrm{L}$ of each hydrolysate was dispensed into the cartridge of the analyser followed by $76 \mathrm{~h}$ of free acidic, neutral and basic amines analysis. Norleucine was employed as the internal standard. Ten microliter $(10 \mu \mathrm{L})$ of the standard solution mixture of the amino acid was also loaded into the analyser. Values of both the standard and samples was recorded and printed out as chromatogram peaks by the chart recorder.

Calculation from the peaks: The net height of each peak produced on the chromatogram (each representing amino acid) was measured. The half-height of each peak was located and the width of the peak at half-height will accurately be measured. Approximate area of each peak was then obtained by multiplying the height with the width of the half height.

\section{Functional property analysis}

The functional properties were determined according to the procedures previously described by Arise et al. (2018). The bulk density (BD) was determined when $10 \mathrm{~g}$ of sample was placed in a graduated cylinder (50 $\mathrm{ml}$ ) and packed by gently tapping the cylinder on the bench top (10 times) to form a reasonable height. The volume of sample was recorded while BD was expressed as grams material per milliliter. For the determination of swelling power, briefly, $2 \mathrm{~g}$ of the sample was weighed and poured into a measuring cylinder and the initial value was noted, $25 \mathrm{ml}$ of distilled water was added, the solution was vigorously shaken and left for 30 mins, 1 and $2 \mathrm{~h}$. The final reading of the swelled sample was taken. The percentage of the swelling index was calculated as: 
Swelling power $(\%)=\frac{\text { Initial reading }}{\text { Final reading }} \times 100$

The water/oil absorption capacity was determined when $1 \mathrm{~g}$ of each sample was dispersed in $10 \mathrm{~mL}$ of distilled water/oil in a 50-mL preweighed centrifuge tube. The dispersion was vortexed for $1 \mathrm{~min}$, allowed to stand for $30 \mathrm{~min}$ and centrifuged at $4000 \times \mathrm{g}$ for $30 \mathrm{~min}$ at room temperature. The supernatant was decanted, excess water/oil in the upper phase was drained for 15 $\mathrm{min}$, and the tube containing the residue was weighed again to determine the amount of water or oil retained per gram of the sample.

WAC or OAC $(\%)=\frac{\text { Volume of water/oil used }- \text { volume of free water/oil }}{\text { Weight of sample used }}$ X100

The emulsifying activity was determined by the method of Wang and Kinsella (1976), with modifications. To verify the emulsifying activity, $20 \mathrm{ml}$ of maize oil was added to $20 \mathrm{ml}$ of suspension protein and subsequently stirred with domestic mixer (Kenwood Appliances, Woking, Surrey, England) for $1 \mathrm{~min}$. The emulsion formed was divided into tubes and centrifuged at $4000 \mathrm{rpm}$ for $6 \mathrm{~min}$. The emulsifying activity was determined as the percentage of the emulsified layer that remained after centrifugation, and the percentage calculation performed using:

$$
\text { WAC or OAC }(\%)=\frac{\text { Mass of the emulsified layer }}{\text { Weight of sample used }} \text { X100 }
$$

The least gelation concentration was done using test tubes containing suspensions of $2,4,6,8$ up to $20 \%$ (w/ v) flour in $5 \mathrm{ml}$ distilled, heated for $1 \mathrm{~h}$ in boiling water, followed by cooling in ice and further cooling for $2 \mathrm{~h}$ at $4{ }^{\circ} \mathrm{C}$. The viscosity was done using capillary tubes and the time it takes for a volume of liquid to pass through the length of the tube.

\section{In vivo studies}

\section{Ethical clearance}

The study protocol was approved and ethic clearance given by the Ethical Committee for Laboratory Animals of School of Agriculture and Agricultural Technology, Federal University of Technology, Akure, Nigeria (FUTA/SAAT/2016/033).

\section{Experimental animals}

A total of thirty (30) weanling Wister albino rats purchased from Department of Biochemistry, Obafemi Awolowo University, Ile-Ife, Osun State, Nigeria were used for the experiment according to the methods of Odebode et al. (2017). Before the arrival of the rats, the rat house and cages were properly cleaned and disinfected using disinfectant. The cages were properly arranged and fitted with feeders and drinkers that can comfortably drop water when nibbled by the rats. The feeders were firmly placed in positions to eliminate feed spillage. The rats were weaned at about 21-25 days, weighing $30-65 \mathrm{~g}$. They were thereafter divided into six groups of five rats each on the basis of initial weight. The rats were housed individually in stainless steel metabolic cages with facilities for separate collection of feaces and urine.

\section{Experimental diet}

Four different experimental diets were developed using maize and almond seed. Fermented yellow maize (FYM) and fermented high quality protein maize (FHQPM) grains were processed into fermented maize flour. Dried germinated high quality protein maize (DGHQPM) and dried high quality protein maize (DHQPM) grains equally processed to maize flour. All the processed maize flours were mixed with almond seed flour at ratio of 70 and $30 \%$, respectively. Basal diet (nitrogen-free diet) was formulated according to Fanimo (Fanimo, A: Substitution of Soyabean and animal by-products for fish meal in pig rations Ph.D Thesis Department of Animal Science. Ibadan, Oyo State: University of Ibadan. Unpublished). such that there was no nitrogen furnished by any of the ingredients. One group of five rats was given nitrogen-free diet (negative control); another four groups of five rats were fed on the remaining four diets containing the test ingredients while the last group was given cerelac as positive control.

\section{Slaughtering and collection of blood samples}

At the 28th day of the experiment, all the rats were starved for about $3 \mathrm{~h}$ and weighed. Each rat was anaesthetized with chloroform inside a dessicator before slaughtering. Blood was collected into bijour bottle containing a speck of dried ethylene diamine tetrachloroacetic acid (EDTA) powder as anti-coagulant. The bottles were immediately capped and the content mixed gently for about $1 \mathrm{~min}$ by repeated inversion thereafter used for various haematological studies.

\section{Measuring of rat organs (Histopathological)}

The organs: heart, kidney and liver were weighed and expressed in $\mathrm{g}$ for each rat.

\section{Haematological studies}

From the blood collected, the packed cell volume (PCV) was estimated by spinning about $75 \mathrm{ml}$ of each sample in heparinized capillary tubes in a hematocrit micro-centrifuge for $5 \mathrm{~min}$ while the total white blood cells (WBC) were determined as described by Lamb (1981). The lymphocytes, neutrophils, monocytes, basophils, platelets 
and eosinophils were also determined as described by Lamb (1981).

\section{Sensory evaluation}

The formulated diets and the control sample were subjected to sensory evaluation as described by Olapade and Aworh (2012). The samples were reconstituted, coded and served warm to ten (10) semi-trained panelist drawn from caregivers (Nursing mothers) attending Child Welfare Clinic in a Comprehensive Health Centre, AdoEkiti, Ekiti State, Nigeria. Each panelist was given coded samples to rate for appearance, aroma, taste, consistency and overall acceptability using 9-point Hedonic scale from dislike extremely (1) to like extremely (9).

\section{Statistical analysis}

Triplicate replications were used to obtain mean values and standard deviations. Statistical analysis was performed with SAS (Statistical Analysis Software 9.1) using one-way ANOVA. Duncan's multiple-range test was carried out to compare the mean values for samples with significant differences taken at $p<0.05$.

\section{Results and discussion}

\section{Proximate composition of formulated flour blends}

The proximate composition is important in determining the quality of food raw materials and often the basis for establishing the nutritional value and consumers' overall acceptance of the product (Mashood and Rizwana 2010). Hence, the proximate compositions of yellow maize, high quality protein maize (QPM) and almond flours blends are presented in Table 1 . The blends were all dried to a minimum level (6-7\%) found in the range of the FAO recommended level $(<10 \%)$ for most dried food samples (National Research Council, NRC 2009), while the remaining compositions were calculated based on the dry weights of the blends. The crude protein content ranged from 24.28 to $27.64 \%$ with the dried germinated QPM (DGQPM) blend having significantly $(p<$ 0.05 ) highest value $(27.64 \%)$ when compared to 26.77 , 26.62 and $23.29 \%$ for dried QPM (DQPM), fermented yellow maize (FYM) and cerelac (commercial control) samples, respectively. The requirements for the maintenance of body protein equilibrium and the optimum pattern of individual indispensable amino acids deviated literarily between the ages of 6 and 24 months (Reeds and Garlick 2003), hence the need to absorb quality and concise amount of protein at the age of $<6$ months. The high protein content of DGQPM ( 28\%) could be attributed to malting of the maize, which encouraged the crop's improved protein as previously reported (Ijarotimi and Keshinro 2012a). However, the current protein contents were above the recommended protein level $(20 \%)$ reported for formulated foods (Akinola et al. 2014) and significantly $(p<0.05)$ higher when compared with $26.87 \%$ reported for fermented-popcornAfrican locust bean-Bambara complementary foods (Ijarotimi and Keshinro 2012b). The crude fat, total ash, crude fibre and carbohydrate contents of the formulated blends (4.69-9.82, 0.55-2.16\%, 0.94-0.97, 62.77-64.67\%, respectively) presented in Table 1 were all within the ranges (10-70\%) recommended for infants and young children (National Research Council, NRC 2009). The implication of this data is that these blends would pose no undesirable bulk density, low caloric density, irritation of the gut mucosa and adverse effects on the efficiency of absorption of various significant nutrients. All these undesirable factors had previously been associated with $O g i$, the common traditional complementary foods (Onabanjo et al. 2008).

\section{Amino acid composition of formulated complementary flour blends}

The amino acid content of complementary foods is a particularly relevant issue to infant feeding in developing countries with continual protein-energy malnutrition challenges (Onabanjo et al. 2008). This might be due to the poor feeding practices and low quality protein commonly associated with plant-based diets (Badamosi et al. 1995). The amino acid compositions of the formulated complementary flour blends are presented in Table 2 . The data showed that the dried germinated QPM (DGQPM) and fermented high QPM (FHQPM) had the highest $(5.81 \mathrm{~g} / 100 \mathrm{~g})$ and least $(3.76 \mathrm{~g} / 100 \mathrm{~g})$ tryptophan contents, respectively. The current result $(3.76-5.81 \mathrm{~g} /$ $100 \mathrm{~g}$ ) is higher than $1.95,1.31$ and $1.25 \mathrm{~g} / 100 \mathrm{~g}$ reported

Table 1 Proximate compositions (d.w.) of blends of maize and almond flours (\%)

\begin{tabular}{lllllll}
\hline Samples & Moisture content & Total ash & Crude fat & Crude fibre & Crude protein & Carbohydrate \\
\hline DQPM & $6.74 \pm 0.02^{\mathrm{b}}$ & $2.01 \pm 0.02^{\mathrm{d}}$ & $7.27 \pm 0.04^{\mathrm{c}}$ & $0.97 \pm 0.02^{\mathrm{a}}$ & $26.77 \pm 0.03^{\mathrm{b}}$ & $62.99 \pm 0.13^{\mathrm{d}}$ \\
DGQPM & $6.15 \pm 0.02^{\mathrm{d}}$ & $2.07 \pm 0.04^{\mathrm{c}}$ & $4.69 \pm 0.40^{\mathrm{d}}$ & $0.94 \pm 0.02^{\mathrm{a}}$ & $27.64 \pm 0.04^{\mathrm{a}}$ & $64.67 \pm 0.48^{\mathrm{b}}$ \\
FYM & $6.54 \pm 0.04^{\mathrm{c}}$ & $0.55 \pm 0.02^{\mathrm{e}}$ & $8.00 \pm 0.04^{\mathrm{b}}$ & $0.96 \pm 0.01^{\mathrm{a}}$ & $26.62 \pm 0.03^{\mathrm{c}}$ & $63.87 \pm 0.10^{\mathrm{c}}$ \\
FHQPM & $7.24 \pm 0.03^{\mathrm{a}}$ & $2.16 \pm 0.01^{\mathrm{b}}$ & $9.82 \pm 0.20^{\mathrm{a}}$ & $0.97 \pm 0.03^{\mathrm{a}}$ & $24.28 \pm 0.02^{\mathrm{d}}$ & $62.77 \pm 0.05^{\mathrm{e}}$ \\
CERC & $3.32 \pm 0.02^{\mathrm{e}}$ & $3.38 \pm 0.03^{\mathrm{a}}$ & $4.49 \pm 0.02^{\mathrm{d}}$ & $0.62 \pm 0.01^{\mathrm{b}}$ & $23.29 \pm 0.02^{\mathrm{d}}$ & $68.20 \pm 0.09^{\mathrm{a}}$ \\
\hline
\end{tabular}

DQPM Dried Quality Protein Maize, DGQPM Dried Germinated Quality Protein Maize, FYM Fermented Yellow Maize, FHQPM Fermented High Quality Protein Maize, CERC Cerelac. Mean values with different superscript on the same column are significant $(p<0.05)$ 
Table 2 Amino acid compositions ( $\mathrm{g} / 100 \mathrm{~g}$ ) of blend of maize and almond seed flours

\begin{tabular}{|c|c|c|c|c|c|c|}
\hline \multirow[t]{2}{*}{ Amino acids } & \multicolumn{6}{|l|}{ Samples } \\
\hline & DQPM & DGQPM & FYM & FHQPM & CERC & ${ }^{*} \mathrm{RDA}$ \\
\hline \multicolumn{7}{|c|}{ Non-essential } \\
\hline Alanine & $3.09 \pm 0.02^{c}$ & $3.78 \pm 0.32^{b}$ & $3.74 \pm 0.02^{b}$ & $3.01 \pm 0.02^{c}$ & $4.09 \pm 0.02^{\mathrm{a}}$ & - \\
\hline Aspartic acid & $1.97 \pm 0.06^{b}$ & $5.61 \pm 2.86^{\mathrm{a}}$ & $2.16 \pm 0.02^{b}$ & $6.54 \pm 0.02^{\mathrm{a}}$ & $2.55 \pm 0.02^{b}$ & - \\
\hline Glutamic acid & $2.65 \pm 0.02^{\mathrm{e}}$ & $9.68 \pm 0.02^{a}$ & $3.05 \pm 0.02^{d}$ & $9.06 \pm 0.02^{b}$ & $3.29 \pm 0.02^{c}$ & - \\
\hline Glycine & $2.89 \pm 0.02^{c}$ & $3.11 \pm 0.02^{b}$ & $3.35 \pm 0.02^{\mathrm{a}}$ & $2.66 \pm 0.09^{d}$ & $3.28 \pm 0.02^{\mathrm{a}}$ & - \\
\hline Proline & $2.89 \pm 0.02^{d}$ & $2.97 \pm 0.02^{c}$ & $3.35 \pm 0.02^{a}$ & $2.12 \pm 0.02^{\mathrm{e}}$ & $3.28 \pm 0.02^{b}$ & - \\
\hline Serine & $8.50 \pm 0.02^{b}$ & $2.40 \pm 0.02^{d}$ & $9.31 \pm 0.02^{a}$ & $1.81 \pm 0.02^{\mathrm{e}}$ & $7.30 \pm 0.02^{c}$ & - \\
\hline \multicolumn{7}{|c|}{ Non-essential } \\
\hline Histidine & $3.83 \pm 0.02^{b}$ & $2.16 \pm 0.02^{c}$ & $4.08 \pm 0.02^{\mathrm{a}}$ & $1.94 \pm 0.02^{d}$ & $4.08 \pm 0.02^{\mathrm{a}}$ & 1.9 \\
\hline Isoleucine & $2.32 \pm 0.02^{d}$ & $2.86 \pm 0.02^{c}$ & $3.01 \pm 0.02^{b}$ & $2.20 \pm 0.02^{\mathrm{e}}$ & $3.11 \pm 0.02^{\mathrm{a}}$ & 2.8 \\
\hline Leucine & $6.51 \pm 0.02^{c}$ & $7.25 \pm 0.02^{b}$ & $2.89 \pm 0.02^{e}$ & $5.66 \pm 0.02^{d}$ & $8.01 \pm 0.02^{a}$ & 6.6 \\
\hline Lysine & $2.85 \pm 0.02^{b}$ & $3.17 \pm 0.02^{\mathrm{a}}$ & $3.06 \pm 0.02^{\mathrm{a}}$ & $2.74 \pm 0.05^{b}$ & $3.04 \pm 0.05^{\mathrm{a}}$ & 5.8 \\
\hline Methionine & $1.22 \pm 0.02^{d}$ & $1.59 \pm 0.02^{d}$ & $1.30 \pm 0.02^{c}$ & $0.96 \pm 0.02^{e}$ & $2.08 \pm 0.02^{a}$ & 2.2 \\
\hline Phenylalanine & $3.38 \pm 0.02^{d}$ & $4.06 \pm 0.02^{b}$ & $3.97 \pm 0.02^{c}$ & $3.13 \pm 0.02^{d}$ & $4.23 \pm 0.02^{\mathrm{a}}$ & 2.8 \\
\hline Threonine & $2.05 \pm 0.02^{d}$ & $2.33 \pm 0.02^{a}$ & $2.19 \pm 0.02^{c}$ & $1.80 \pm 0.02^{\mathrm{e}}$ & $2.27 \pm 0.01^{b}$ & 3.4 \\
\hline Arginine & $6.86 \pm 0.02^{b}$ & $4.34 \pm 0.02^{c}$ & $6.98 \pm 0.07^{a}$ & $3.66 \pm 0.02^{d}$ & $2.55 \pm 0.02^{c}$ & 2 \\
\hline Cystine & $0.82 \pm 0.02^{d}$ & $0.99 \pm 0.02^{b}$ & $0.93 \pm 0.02^{c}$ & $0.53 \pm 0.02^{b}$ & $1.39 \pm 0.01^{a}$ & - \\
\hline Tyrosine & $2.25 \pm 0.02^{c}$ & $2.42 \pm 0.02^{b}$ & $2.25 \pm 0.02^{c}$ & $1.93 \pm 0.02^{d}$ & $2.58 \pm 0.02^{\mathrm{a}}$ & - \\
\hline Tryptophan & $4.72 \pm 0.01^{b}$ & $5.81 \pm 0.02^{\mathrm{a}}$ & $4.79 \pm 0.01^{c}$ & $3.76 \pm 0.02^{b}$ & $1.95 \pm 0.02^{d}$ & 1.25 \\
\hline TSAA (Meth + Cys) & 2.04 & 2.58 & 2.23 & 0.94 & 3.47 & 2.20 \\
\hline AAA (Phe + Tyr + Trp) & 6.35 & 7.29 & 6.98 & 5.85 & 7.76 & 2.80 \\
\hline TIAA & 35.73 & 35.09 & 34.73 & 28.07 & 36.94 & 33.90 \\
\hline
\end{tabular}

DQPM Dried Quality Protein Maize, DGQPM Dried Germinated Quality Protein Maize, FYM Fermented Yellow Maize, FHQPM Fermented High Quality Protein Maize, CERC Cerelac. TSAA Total Sulphur Amino Acid, AAA Aromatic Amino Acid, TIAA Total Indispensable Amino Acid, *RDA Recommended Daily Allowance (United States Department of Agriculture, USDA 2018). Values with different superscript on the same row are significant $(p<0.05)$

for commercial cerelac (control), fermented popcornwonderful kola seed flour blend (Ijarotimi et al. 2015) and USDA Recommended Daily Allowance (United States Department of Agriculture, USDA 2018). The higher tryptophan content obtained for the formulatedQPM blends when compared to other products from common maize might be due to the contribution of reported higher tryptophan content of QPM than common maize (Ikujenlola and Ogunba 2018). However, FHQPM has the highest glutamic $(9.06 \mathrm{~g} / 100 \mathrm{~g})$ and aspartic $(6.54 \mathrm{~g} / 100 \mathrm{~g})$ acid when compared to dried quality protein maize (DQPM) $(2.65 ; 2.65 \mathrm{~g} / 100 \mathrm{~g})$ and cerelac $(3.29 ; 2.55 \mathrm{~g} / 100 \mathrm{~g})$, respectively. The fermentation process might have positively affected the high proportions of these acidic amino acids in FHQPM. Meanwhile, the DQPM has the highest total indispensable amino acid $(35.01 \mathrm{~g} / 100 \mathrm{~g})$ while FHQPM has the least $(27.28 \mathrm{~g} /$ $100 \mathrm{~g}$ ) as shown in Table 2. Although, all the indispensable amino acids were present in the amino acid profile but quite a number did not meet the FAO and WHO (1991) referenced values. A lower score for any of the indispensable acids designated the limiting characteristics of the amino acids and gave an indication of the protein quality of such plant-based food materials when compared with food materials produced from animal sources (Ogunlade et al. 2005).

\section{Functional properties of the formulated flour blends}

The functional property of food material is an important determinant in the application and use of such food material for various food productions (Alawode et al. 2017). Table 3 showed the functional properties of the formulated complementary foods in comparison with the control. The least gelation concentration (LGC) of the samples ranged from 2 to $6 \%$ with the least LGC (2\%) obtained for dried quality protein maize (DQPM), fermented yellow maize (FYM) and fermented high quality protein maize (FHQPM), respectively while dried germinated quality protein maize (DGQPM) had the highest (6\%). This implied that the DGQPM might possess reduced viscosity, plasticity and elasticity, thus forming a low dietary bulk, which is highly favourable for a good complementary diet (Omueti et al. 2009). Studies have shown that foods that formed gels at low concentrations 
Table 3 Functional properties of blends of maize and almond seed flours

\begin{tabular}{llllll}
\hline Functional properties & Samples & & & & \\
\cline { 2 - 6 } & DQPM & DGQPM & FYM & FHQPM & CERC \\
\hline Least gelation (\%) & $2.00^{\mathrm{c}}$ & $6.00^{\mathrm{a}}$ & $2.00^{\mathrm{c}}$ & $2.00^{\mathrm{c}}$ & $4.00^{\mathrm{b}}$ \\
Water absorption capacity (g/g) & $295.00 \pm 5.00^{\mathrm{b}}$ & $150.00 \pm 0.00^{\mathrm{d}}$ & $295.00 \pm 5.00^{\mathrm{b}}$ & $240.00 \pm 10.00^{\mathrm{c}}$ & $350.00 \pm 10.00^{\mathrm{a}}$ \\
Oil absorption capacity (g/g) & $214.66 \pm 4.50^{\mathrm{b}}$ & $264.66 \pm 9.50^{\mathrm{a}}$ & $173.00 \pm 9.00^{\mathrm{e}}$ & $182.00 \pm 0.00^{\mathrm{d}}$ & $205.66 \pm 4.50^{\mathrm{c}}$ \\
Bulk density (g/ml) & $0.80 \pm 0.00^{\mathrm{a}}$ & $0.64 \pm 0.05^{\mathrm{b}}$ & $0.54 \pm 0.01^{\mathrm{c}}$ & $0.66 \pm 0.00^{\mathrm{b}}$ & $0.77 \pm 0.02^{\mathrm{a}}$ \\
Emulsion capacity & $52.50 \pm 0.50^{\mathrm{a}}$ & $51.00 \pm 1.00^{\mathrm{ab}}$ & $50.50 \pm 1.00^{\mathrm{b}}$ & $51.50 \pm 1.50^{\mathrm{ab}}$ & $51.00 \pm 1.00^{\mathrm{ab}}$ \\
Swelling power & $3.10 \pm 0.10^{\mathrm{a}}$ & $2.50 \pm 0.10^{\mathrm{c}}$ & $2.85 \pm 0.10^{\mathrm{b}}$ & $2.58 \pm 0.08^{\mathrm{c}}$ & $3.02 \pm 0.07^{\mathrm{a}}$ \\
Viscosity (cPas) & $1.50 \pm 3.00^{\mathrm{b}}$ & $1.70 \pm 2.00^{\mathrm{a}}$ & $1.70 \pm 8.00^{\mathrm{a}}$ & $1.70 \pm 8.00^{\mathrm{a}}$ & $1.50 \pm 3.00^{\mathrm{b}}$ \\
\hline
\end{tabular}

DQPM Dried Quality Protein Maize, DGQPM Dried Germinated Quality Protein Maize, FYM Fermented Yellow Maize, FHQPM Fermented High Quality Protein Maize, CERC Cerelac. Values with different superscript on the same row are significant $(p<0.05)$

were not ideal for infant diet, because of the high dilution rate in an attempt to improve digestibility-volume relation (Ezeji and Ojimelukwe 1993; Obatolu and Cole 2000).

Water absorption capacity (WAC) is an index of the maximum amount of water that a food product would absorb and retain (Marero et al. 1988). It is also the ability of a product to associate with water under a limiting water condition. WAC is desirable for food systems to improve yield and consistency as well as given body to the food (Osundahunsi et al. 2003). The WAC of the formulated diets ranged from 150 to $295 \mathrm{~g} / \mathrm{g}$ with DQPM and FYM having the highest values, respectively, which might be due to their reported protein contents (Table 1). However, the lowest WAC of DGQPM might be as a result of the microbial activities of the flour blend but with a resultant extended shelf-live (Giami and Bekeham 1992).

Oil absorption capacity (OAC) of the flour blend is the ability of its protein to physically bind fat by capillary attraction and it is of great importance since fat is well known as flavor retainer to increase the mouth-feels of foods (Omueti et al. 2009). The OAC values ranged from 173.00 to $264.66 \mathrm{~g} / \mathrm{g}$ with DGQPM and FYM having the significantly $(p<0.05)$ highest and least values, respectively. However, high OAC of DGQPM might be as a result of its positively charged amino acid compositions that caused its protein to bind oil (Appiah et al. 2011).

Bulk density (BD) is a measure of heaviness of a flour sample, thus given an indication that the relative volume of the composite flour in a package would not reduce excessively during storage (Alawode et al. 2017). The BD ranged from 0.54 to $0.80 \mathrm{~g} / \mathrm{ml}$ while emulsification capacity (EC) values ranged from 51 to $53 \%$. The different processing methods of producing the flour blends might have contributed to their different BD contents (Akpata and Akubor 1999). This is indicated by the highest and lowest values obtained for the DQPM and FYM, respectively.
The swelling power (SP) capacity is an important factor used to determine the amount of water that food samples would absorb as well as the degree of swelling within a given time (Ijarotimi and Keshinro 2012a). The SP ranged from 2.50 to 3.10 with no significant difference $(p>0.05)$ between the control and DQPM diets, whereas, DQPM and DGQPM blends have the highest and least SP, respectively. This implied that the DQPM with the highest SP when compared to the other complementary diets (DGQPM, FYM and FHQPM) would produce a thick viscous gruel.

\section{Nutritional quality of formulated flour blends}

The results of nutritional quality of the food samples are shown in Table 4. The total digestibility (TD), biological value (BV), protein retention efficiency (PRE), nitrogen retention (NR) and net protein utilization (NPU) are given as 97.76-98.00, 9.83-29.32\%, 4.76-5.57, 7.31-8.03, 9.80-35.67, respectively. However, the food efficiency ratio (FER), protein efficiency ratio (PER), net protein retention (NPR) are $0.07-0.08,0.58-1.30,0.33-0.34$, respectively. All the experimental formulated diets had significantly $(p<0.05)$ nutritional (protein) qualities similar to the commercial control (cerelac) with the exception of BV and NPU. However, the BV and NPU of the experimental diets are significantly $(p<0.05)$ higher than those of basal diet (Table 4). The differences in the nutritional (protein) qualities of dried germinated QPM (DGQPM) and commercial cerelac might be due to the differences in their protein contents ( 26 and $\sim 23 \%)$, respectively. Interestingly, the $\mathrm{BV}$ of the current blends $(10-29 \%)$ did not fall within the ranges $(70-100 \%)$ reported for protein materials to be used as adequate and good nutritional quality sources for complementary food formulation (Ijarotimi and Keshinro 2013). This could be attributed to the complex metabolic process of the almond seed-enriched blends during which lipids, carbohydrates and storage protein within the seeds were broken down and prevented the bioavailability of the required protein (Jachmanian et al. 1995). Moreover, the 
Table 4 Nutritional quality of blend of maize and almond seed flours

\begin{tabular}{|c|c|c|c|c|c|c|}
\hline \multirow{2}{*}{$\begin{array}{l}\text { Nutritional } \\
\text { qualities }\end{array}$} & \multicolumn{6}{|l|}{ Samples } \\
\hline & DQPM & DGQPM & FYM & FHQPM & CERC & BASAL \\
\hline FER & $0.08 \pm 0.01^{a}$ & $0.08 \pm 0.01^{a}$ & $0.08 \pm 0.01^{\mathrm{a}}$ & $0.07 \pm 0.01^{b}$ & $0.08 \pm 0.01^{\mathrm{a}}$ & $0.05 \pm 0.00^{c}$ \\
\hline PER & $0.58 \pm 0.01^{c}$ & $0.61 \pm 0.01^{b}$ & $0.58 \pm 0.01^{c}$ & $0.58 \pm 0.01^{c}$ & $1.30 \pm 0.02^{\mathrm{a}}$ & $0.35 \pm 0.00^{d}$ \\
\hline NPR & $0.33 \pm 0.02^{b}$ & $0.34 \pm 0.01^{b}$ & $0.33 \pm 0.02^{b}$ & $0.33 \pm 0.02^{b}$ & $1.03 \pm 0.01^{a}$ & $0.30 \pm 0.01^{c}$ \\
\hline TD (\%) & $97.76 \pm 1.05^{\mathrm{a}}$ & $98.00 \pm 1.00^{\mathrm{a}}$ & $97.86 \pm 0.05^{\mathrm{a}}$ & $97.63 \pm 0.05^{a}$ & $97.76 \pm 0.05^{a}$ & $97.30 \pm 0.01^{c}$ \\
\hline BV (\%) & $9.83 \pm 0.05^{\mathrm{e}}$ & $36.73 \pm 0.03^{b}$ & $32.78 \pm 0.01^{c}$ & $29.32 \pm 0.02^{d}$ & $69.51 \pm 0.01^{\mathrm{a}}$ & $7.01 \pm 0.00^{f}$ \\
\hline PRE & $4.80 \pm 0.02^{d}$ & $5.57 \pm 0.06^{b}$ & $4.76 \pm 0.01^{d}$ & $4.99 \pm 0.01^{c}$ & $16.62 \pm 0.02^{\mathrm{a}}$ & $2.28 \pm 0.01^{e}$ \\
\hline NR & $7.31 \pm 0.01^{e}$ & $8.03 \pm 0.06^{b}$ & $7.89 \pm 0.00^{c}$ & $7.80 \pm 0.00^{d}$ & $8.81 \pm 0.01^{\mathrm{a}}$ & $7.04 \pm 0.04^{f}$ \\
\hline NPU & $9.80 \pm 0.01^{e}$ & $35.67 \pm 0.58^{b}$ & $32.07 \pm 0.67^{c}$ & $28.59 \pm 0.01^{d}$ & $68.00 \pm 1.00^{\mathrm{a}}$ & $7.83 \pm 0.00^{f}$ \\
\hline
\end{tabular}

DQPM Dried Quality Protein Maize, DGQPM Dried Germinated Quality Protein Maize, FYM Fermented Yellow Maize, FHQPM Fermented High Quality Protein Maize, CERC Cerelac. FER Food Efficiency Ratio, PER Protein Efficiency Ratio, NPR Net Protein Retention, TD True Digestibility, BV Biological Value, PRE Protein Retention Efficiency, NR Nitrogen Retention, NPU Net Protein Utilization. Values with different superscript on the same row are significant $(p<0.05)$

current BV in this study is comparatively low to the $41-$ 60 (Ijarotimi and Keshinro 2012a), 56.16-89.92 (Abiose et al. 2015) and 88.31-100\% (Akinsola et al. 2017) previously reported for different formulated complementary foods from germinated popcorn-bambara groundnutAfrican locust bean and quality protein maize-common maize, respectively.

\section{Hematological characteristics of rats fed with the formulated flour blends}

The result of hematological characteristics of rats fed with the blends of quality protein maize (QPM) and almond seed flours is shown in Table 5 . The packed cell volume (PCV), white blood cells (WBC) and platelets (RBC) of the rats fed with the flour blends were 31.00$49.00, \quad 30.2-42.4 \times 10^{2}, \quad 17.14-22.8 \times 10^{4}$, respectively. Meanwhile, the other blood components such as neutrophil, eosinophil, basophil, monophil and lymphocytes were obtained as 43.40-53.4, 0.60-1.6, 0.01-0.8, 0.2-0.6 and 46.00-53.20, respectively. The different processing methods employed in the production of these formulated blends significantly $(p<0.05)$ improved the haematological data of the experimental rats. For instance, the data (Table 5) showed that rats fed with the fermented high QPM (FHQPM) and dried germinated QPM (DGQPM) have significantly $(p<0.05)$ higher PCV (49 and $47.40 \%)$ and RBC $\left(228\right.$ and $\left.280 \times 10^{3}\right)$ but lower WBC (42 and $30.2 \times 10^{2}$ ) than the PCV, RBC and WBC of those fed with cerelac $\left(47.20 \% ; 280 \times 10^{3} ; 51 \times 10^{2}\right)$, respectively. Notably, the rats fed with FHQPM, which had better PCV and RBC than those fed with DGQPM, showed that the fermentation process improved the blood formation ability of the blends to prevent the pathogenesis of anaemia. This observation is contrary to the protein content improvement observed with germination processing method of producing the blend (Table 1). Meanwhile, a previous study had reportedly linked the association of low PCV, RBC and serum protein with protein deficiency (Aletor and Egberongbe 1992). Thus, the high PCV and RBC but low WBC of the rats fed on the current blends relative to cerelac showed that the blends possessed the greater potentials of blood,

Table 5 Hematological characteristics of rats fed with the blends of maize and almond seed flour

\begin{tabular}{|c|c|c|c|c|c|}
\hline \multirow{2}{*}{$\begin{array}{l}\text { Hematological } \\
\text { characteristics }\end{array}$} & \multicolumn{5}{|l|}{ Samples } \\
\hline & DQPM & DGQPM & FYM & FHQPM & CERC \\
\hline PCV (\%) & $36.40 \pm 5.07^{c}$ & $47.40 \pm 11.32^{\mathrm{ab}}$ & $31.00 \pm 12.14^{c}$ & $49.00 \pm 7.61^{a}$ & $47.20 \pm 4.15^{\mathrm{ab}}$ \\
\hline WBC $\left(\times 10^{3} / \mathrm{mm}^{3}\right)$ & $3.20 \pm 0.20^{b}$ & $3.00 \pm 0.90^{b}$ & $3.00 \pm 0.50^{b}$ & $4.20 \pm 1.10^{\mathrm{ab}}$ & $5.10 \pm 1.20^{\mathrm{a}}$ \\
\hline PLATELETS $\left(\times 10^{3} / \mathrm{mm}^{3}\right)$ & $\begin{array}{l}190.00 \pm \\
31.07^{d}\end{array}$ & $\begin{array}{l}280.00 \pm \\
39.93^{\mathrm{a}}\end{array}$ & $\begin{array}{l}171.00 \pm \\
29.45^{\mathrm{e}}\end{array}$ & $228.00 \pm 36.90^{b}$ & $208.00 \pm 34.43^{c}$ \\
\hline NEUT (\%) & $43.40 \pm 3.23^{c}$ & $51.80 \pm 3.64^{\mathrm{a}}$ & $53.40 \pm 3.58^{\mathrm{a}}$ & $47.00 \pm 2.18^{b}$ & $49.00 \pm 2.00^{\mathrm{ab}}$ \\
\hline EOS (\%) & $1.60 \pm 1.14^{\mathrm{a}}$ & $1.60 \pm 1.14^{\mathrm{a}}$ & $0.60 \pm 0.01^{d}$ & $1.20 \pm 0.04^{b}$ & $1.00 \pm 0.01^{c}$ \\
\hline BASO (\%) & $0.80 \pm 0.05^{\mathrm{a}}$ & NIL & $0.40 \pm 0.05^{b}$ & $0.20 \pm 0.01^{c}$ & NIL \\
\hline MONO (\%) & $0.60 \pm 0.05^{\mathrm{a}}$ & $0.20 \pm 0.05^{b}$ & $0.20 \pm 0.02^{b}$ & $0.60 \pm 0.04^{a}$ & $0.20 \pm 0.05^{b}$ \\
\hline LYMPH (\%) & $53.20 \pm 7.30^{\mathrm{a}}$ & $46.00 \pm 7.50^{b}$ & $47.40 \pm 4.72^{b}$ & $53.60 \pm 4.04^{a}$ & $48.80 \pm 3.27^{b}$ \\
\hline
\end{tabular}

DQPM Dried Quality Protein Maize, DGQPM Dried Germinated Quality Protein Maize, FYM Fermented Yellow Maize, FHQPM Fermented High Quality Protein Maize, CERC Cerelac. PVC Packed Cell Volume, WBC White Blood Cell, NEUT Neutrophil, EOS Eosinophil, BASO Basophil, MONO Monocytes, LYMPH Lymphocytes. Values with different superscript on the same row are significant $(p<0.05)$. 
antibody and cell-mediated immunity formation (Ijarotimi et al. 2015). Furthermore, previously reported findings (Ijarotimi and Keshinro 2012b; Abiose et al. 2015) had supported the above observation on flour blends from plant origins to contribute to the good haematological indices (high PCV and RBC with low WBC) of the fed subjects. However, there exist no significant differences $(p>0.05)$ in the other indices (neutrophil, eosinophil, basophil, monophil and lymphocytes) of the rats fed with the formulated diets relative to cerelac. This implied that the formulated diet did not contain any possible antinutritional factors (such as phytate, oxalate, etc.) above the health-hazardous level that could adversely affect the haematological and immune status of the animals (Ijarotimi et al. 2015).

\section{Effect of the formulated complementary diets on the quality and development of the internal organs of the experimental animals}

The protein (nutritional quality) of the internal organs of the animals is a determinant of the physiological needs of the rat, which denoted their biochemical (haemotological) indices and resultant growth and development patterns of the animals after feeding with the formulated diets. The result of the effect of the complementary diet on the quality of the internal organs of the experimented animals is presented in Fig. 1. The result showed that the protein contents of the internal organs (liver, kidney and tissue) of the experimental animals (45.19-49.49, 45.85-49.21 and 46.56-51.88 mgN/g) after feeding with formulated blends were significantly $(p<$ $0.05)$ lower than those $(55.04,55.91$ and $53.72 \mathrm{mgN} / \mathrm{g}$ ) of rats fed with the cerelac (commercial control) respectively. Notably, the low BV (10-37\%) and NPU (10-36) of the complimentary diets (Table 4) when compared to BV (70\%) and NPU (68) of cerelac, even with similar digestibility $(\sim 98 \%)$ might have contributed to the low protein contents of the internal organs of the formulated diets-fed rats.

However, the growth and development of the internal organs (kidney, liver and heart), which could be either larger (overweight) or smaller (underweight) than the normal (control) sizes, depicted the growth patterns and health status of the animals. Therefore, the result of the effect of the complementary diet on the development (weight) of the internal organs of the experimental animals is presented in Fig. 2. The weights of the internal organs (liver, kidney and tissue) of the animals fed with experimental diets (1.362.7, 0.54 and $0.25 \mathrm{~g}$ ) were similar when compared to those fed on cerelac $(1.98,0.58$ and $0.25 \mathrm{~g})$, respectively. The present study is contrary to the past finding (Ijarotimi and Keshinro 2012b) that reported less weights of the internal organs of the animals fed with fermented popcorn-African locust bean-Bambara groundnut flour blends when compared to cerelac. Although, the rats fed with dried germinated QPM (DGQPM) sample have better protein contents and weights of internal organs when compared with those fed on fermented high QPM (FHQPM) sample but the current data generally revealed that the formulated diets did not result in abnormal development of the vital organs of the rats. Similar observations of no-toxic and high-safe consumption effects were previously reported on the rats fed with soybean-cowpea tempe-maize-based (Osundahunsi and Aworh 2003),

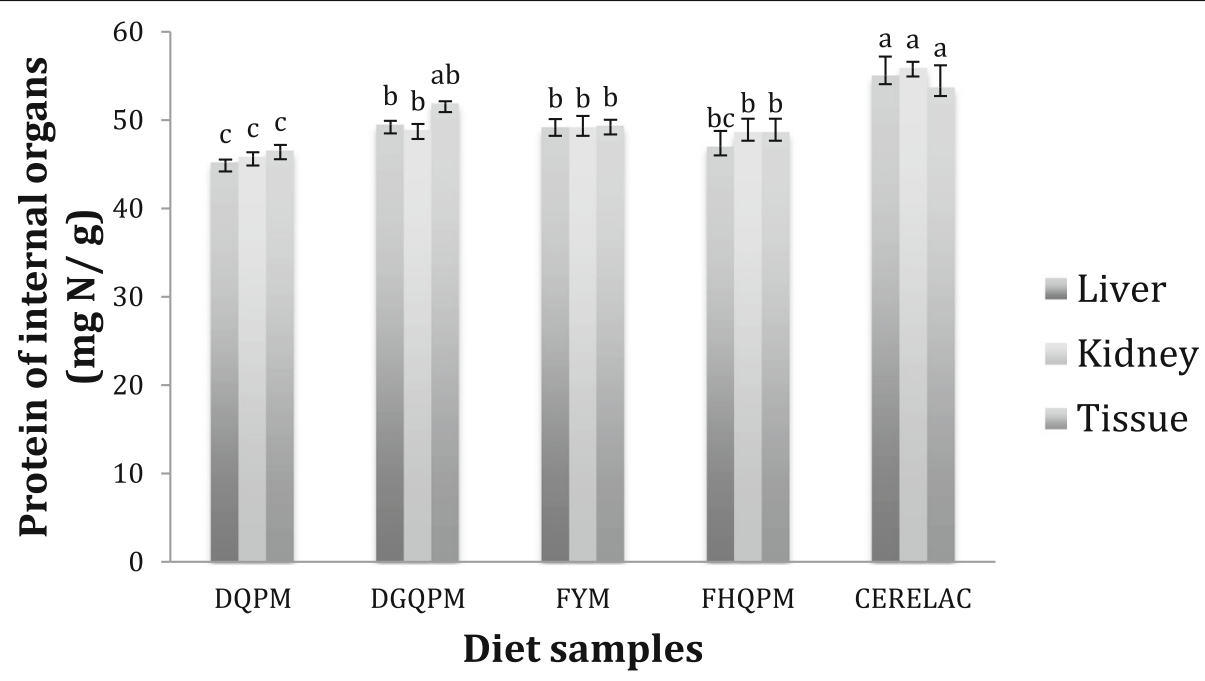

Fig. 1 Effect of the complementary diet on the quality (protein) of the internal organs of the feeding animals. DQPM = Dried Quality Protein Maize, DGQPM = Dried Germinated Quality Protein Maize, FYM = Fermented Yellow Maize, FHQPM = Fermented High Quality Protein Maize. Bars with different superscript on the same column are significant $(p<0.05)$ 


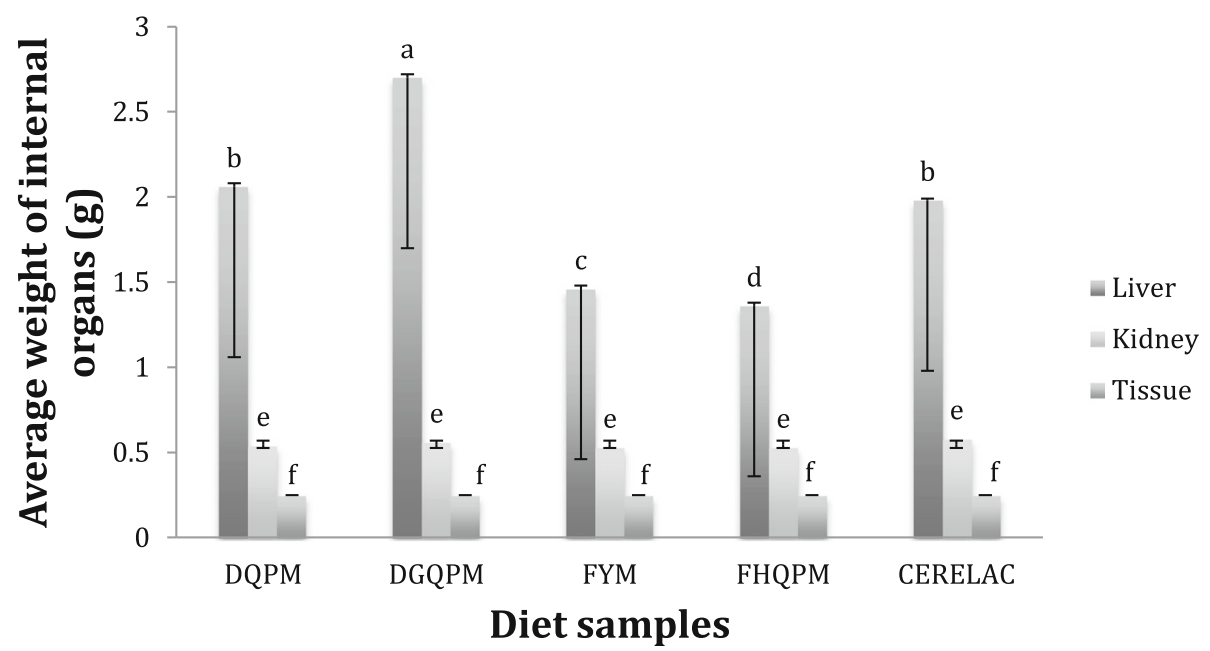

Fig. 2 Effect of the complementary diet on the internal organs development of the feeding animals. DQPM = Dried Quality Protein Maize, DGQP $\mathbf{M}=$ Dried Germinated Quality Protein Maize, FYM = Fermented Yellow Maize, FHQPM = Fermented High Quality Protein Maize. Bars with different superscript on the same column are significant $(p<0.05)$

cassava-based (Onabanjo et al. 2008) and unripe plantain-soybean cake-rice bran-based (Odebode et al. 2017) complementary diets.

\section{Sensory attributes of the formulated complementary diets}

The sensory attributes of the complimentary diets presented in Table 6 showed that the panelists generally accepted (7.00-8.01) all the samples that were produced from the almond-maize flour blends except for the aroma of the products, which were neither liked nor disliked (5.00-5.88) by the panelists. Notably, the panelists did not report any significant difference $(p>0.05)$ between the colour of the control (cerelac) and germinated (DGQPM) samples. The reason could have been that most of the minor components such as phenolic compounds might have been leached out during the germination process of producing DGQPM, thereby helping to improve its colour. Although, the control (cerelac) sample had a significantly $(p<0.05)$ better texture than all the formulated diets but there was no observable difference in the consistency of the control, DQPM and DGQPM samples. Past studies on the maize-based snacks (Arise et al. 2018) and custard (Akinwale et al. 2017) were in agreement with the current work, which revealed no negative effect on the sensory (organoleptic) attributes of the complimentary diets after supplementation with high protein legume/oil crops, such as Bambara groundnut and soybean, respectively.

\section{Conclusion}

The study revealed that the complementary food formulated from almond seed, yellow maize and high quality protein maize compared favorably with cerelac to meet the nutritional needs of children above six months of age. The dual germination and fermentation methods employed during the processing stages thus, improved the nutritional qualities (protein contents, digestibility and amino acid composition) and haematological indices of the formulated complementary foods, respectively.

Table 6 Sensory attributes of the complementary diets

\begin{tabular}{|c|c|c|c|c|c|}
\hline \multirow{2}{*}{$\begin{array}{l}\text { Sensory } \\
\text { attributes }\end{array}$} & \multicolumn{4}{|c|}{ DIET SAMPLES } & \multirow[b]{2}{*}{ CERELAC } \\
\hline & DQPM & DGQPM & FYM & FHQPM & \\
\hline Colour & $6.39 \pm 0.50^{b}$ & $6.77 \pm 0.80^{\mathrm{a}}$ & $6.17 \pm 0.38^{c}$ & $6.28 \pm 0.46^{c}$ & $6.78 \pm 0.80^{a}$ \\
\hline Taste & $6.61 \pm 0.69^{b}$ & $6.28 \pm 0.46^{b}$ & $6.33 \pm 0.48^{b}$ & $6.50 \pm 0.51^{b}$ & $7.61 \pm 0.70^{a}$ \\
\hline Aroma & $5.88 \pm 0.83^{\mathrm{a}}$ & $5.11 \pm 0.32^{d}$ & $5.00 \pm 0.02^{d}$ & $5.33 \pm 0.48^{b}$ & $5.89 \pm 0.85^{a}$ \\
\hline Consistency & $6.39 \pm 0.69^{a}$ & $6.33 \pm 0.48^{a}$ & $6.11 \pm 0.32^{b}$ & $6.00 \pm 0.03^{b}$ & $6.40 \pm 0.70^{a}$ \\
\hline Texture & $6.72 \pm 0.89^{b}$ & $6.22 \pm 0.42^{c}$ & $6.11 \pm 0.32^{\mathrm{cd}}$ & $6.00 \pm 0.02^{d}$ & $7.73 \pm 0.90^{\mathrm{a}}$ \\
\hline $\begin{array}{l}\text { Overall } \\
\text { acceptability }\end{array}$ & $7.00 \pm 0.02^{b}$ & $7.00 \pm 0.02^{b}$ & $7.00 \pm 0.03^{b}$ & $7.00 \pm 0.01^{b}$ & $8.01 \pm 0.02^{a}$ \\
\hline
\end{tabular}


The low swelling index, water absorption capacity, loose and bulk density values in this work indicated that higher amount of the flour particles could bond together and increase the beneficial effect of energy contents of these diets. Thus, it could be inferred that the functional properties of these diets would lead to production of appropriate complementary diets with adequate texture, dietary bulk and caloric density. The significant similar quality and weights of the internal organs of the experimental animals after feeding with formulated blends and cerelac revealed their safe consumption with no possible adverse health effects, thus adding value to the locally produced almond seeds. Moreover, the improved nutritional qualities of the almond-quality protein maizeyellow maize flour blends therefore, encouraged its utilization in the global preparation of future complimentary foods for young children.

\section{Abbreviations}

BASO: Basophil; BV: Biological value; CERC: Cerelac; DGQPM: Dried germinated quality protein maize; DQPM: Dried quality protein maize; EDTA: Ethylene diamine tetrachloroacetic acid; EOS: Eosinophil; FER: Food efficiency ratio; FHQPM: Fermented high quality protein maize; FYM: Fermented yellow maize; LYMPH: Lymphocytes; MONO: Monocytes; NEUT: Neutrophil; NPR: Net protein retention; NPU: Net protein utilization; NR: Nitrogen Retention; PER: Protein efficiency ratio; PRE: Protein retention efficiency; PVC: Packed cell volume; QPM: Quality protein maize; RDA: Recommended daily allowance; TArAA: Total aromatic amino acid; TD: True digestibility; TEAA: Total essential amino acid; TSAA: Total sulphur amino acid; TSM: Technicon Sequential Multi-Sample; WBC: White blood cell

\section{Acknowledgements}

The authors would like to acknowledge the laboratory staff of the Department of Food Science and Technology, Federal University of Technology, Akure, Nigeria.

\section{Authors' contributions}

Adesanmi, R.A. collected and analyzed the data as well as prepared the draft of the manuscript. Malomo, S.A. thoroughly read and edited the manuscript as well served as the corresponding author of the manuscript. Fagbemi, T.N. designed the experiment, supervised the study, read and edited the manuscript. The authors read and approved the final manuscript.

\section{Funding}

N/A

Availability of data and materials

Data are available upon request by contacting the authors.

\section{Competing interests}

The authors declare that they have no competing interests.

\section{Author details}

'Ekiti State Primary Health Care Development Agency, Ado Ekiti, Nigeria. ${ }^{2}$ Department of Food Science and Technology, Federal University of Technology, Akure, Nigeria.

Received: 25 May 2020 Accepted: 4 September 2020 Published online: 23 October 2020

\section{References}

Abiose, S., \& Ikujenlola, A. (2014). Comparison of chemical composition, functional properties and amino acids composition of quality protein maize and common maize. African Journal of Food Science and Technology, 81-89. https://doi.org/10.14303/ajfst.2014.024.
Abiose, S., Ikujenlola, A., \& Abioderin, F. (2015). Nutritional quality assessment of complementary foods produced from fermented and malted quality protein maize fortified with soybean flour. Polish Journal of Food and Nutrition Science, 49-56. https://doi.org/10.1515/pjfns-2015-0004.

Ahren, S., Venkatachalam, M., Mistry, A., Lapsley, K., \& Sathe, S. (2005). Almond (Prunus dulcis L.) protein quality. Journal of Plant Foods for Human Nutrition, 123-128. https://doi.org/10.1007/s11130-005-6840-2.

Akinola, O., Opreh, O., \& Hammed, I. (2014). Formulation of local ingredient-based complementary food in south-West Nigeria. Journal of Nursing and Health Science, 3(6), 57-61.

Akinsola, A., Idowu, M., Oke, E., Idowu, O., \& Laniran, A. (2017). Nutritional evaluation of maize-millet based complementary foods fortified with soybean. Annals. Food Science and Technology, 18, 173-182.

Akinwale, T. E., Shittu, T. A., Adebowale, A. R. A., Adewuyi, S., \& Abass, A. B. (2017) Effect of soy protein isolate on the functional, pasting, and sensory acceptability of cassava starch-based custard. Food Science \& Nutrition, 5, 1163-1169.

Akpata, M. I., \& Akubor, P. I. (1999). Chemical composition and selected functional properties of sweet orange (Citrus sinesis) seed flour. Journal of Plant Foods for Human Nutrition, 353-362. https://doi.org/10.1023/a:1008153228280.

Alamu, E., Gonde, T., Akello, J., Sakala, N., Munthali, G., Mukanga, M., et al. (2018). Nutrient and aflatoxin contents of traditional complementary foods consumed by children of 6-24 months. Food Science \& Nutrition. https://doi. org/10.1002/fsn3.621

Alawode, E., Idowu, M., Adeola, A., Oke, E., \& Omoniyi, S. (2017). Some quality attributes of complementary food produced from flour blends of orange flesh sweet potato, sorghum, and soybean. Croatia Journal of Food Science and Technology, 122-129. https://doi.org/10.17508/CJFST.2017.9.2.06.

Aletor, V., \& Egberongbe, O. (1992). Feeding differently processed soybean. Part 2: An assessment of haematological responses in the chicken diet. Nahrung, 364-369. https://doi.org/10.1002/food.19920360405.

AOAC (2005). Official methods of analysis 18th edn, Association of Official Analytical Chemists. Washington, DC: Official methods of analysis 18th edn, Association of Official Analytical Chemists.

Appiah, F., Asibuo, J., \& Kumah, P. (2011). Physicochemical and functional properties of bean flours of three cowpea (Vigna unguiculata L. Walp) varieties in Ghana. African Journal of Food Science, 5, 100-104.

Arise, A. K., Ganiyat, T., \& Malomo, S. (2020). Amino acid profile, pasting and sensory properties of croissant snacks produced from wheat-fermented Bambara flour. Legume Science, E53, 1-9. https://doi.org/10.1002/leg3.53.

Arise, A. K., Oyeyinka, S. A., Dauda, A. O., Malomo, S. A., \& Allen, B. O. (2018). Quality evaluation of maize snacks fortified with bambara groundnut flour. Annals. Food Science and Technology, 19, 283-291.

Badamosi, E., Ibrahim, L., \& Temple, V. (1995). Nutritional evaluation of a locally formulated weaning food, JUTH-PAP. West African Journal of Biological Science, 6, 85-93.

Bidlingmeyer, B., Cohen, S., \& Tarvin, T. (1984). The PICO-TAG method for amino acid determination. Journal of Chromatography, 33, 93-104.

Esquius, L., Segura, R., Oviedo, G. R., Massip-Salcedo, M., \& Javierre, C. (2020). Effect of almond supplementation on non-esterified fatty acid values and exercise performance. Nutrients, 12(3), 635-640.

Ezeji, C., \& Ojimelukwe, P. (1993). Effect of fermentation on the nutritional quality and functional properties of infant food formulations prepared from Bambarra-groundnut, fluted-pumkin and millet seeds. Journal of Plant Foods for Human Nutrition, 267-276. https://doi.org/10.1007/BF01088322.

Fagbemi, T., Oboh, G., \& Adedokun, O. (2018). Chemical and nutritional evaluation of complementary food from blends of quality protein maize and conophor nuts (Tetracarpidium conophorum). Asian Food Science Journal, 1-6. https://doi.org/10.9734/AFSJ/2018/44611.

FAO \& WHO (1991). Codex Alimentarius: Guidelines on formulated supplementary foods for older infants and young children. Rome: FAO/WHO Joint Publications.

Gehrke, C. W., Wall, L. L., Absheer, J. S., Kaiser, F. E., \& Zumwalt, R. W. (1985). Sample preparation for chromatography of amino acids: Acid hydrolysis of proteins. Journal of the Association of Official Analytical Chemists, 68, 811-821.

Gemede, H. F. (2020). Nutritional and antinutritional evaluation of complementary foods formulated from maize, pea, and anchote flours. Food Science \& Nutrition, 8(4), 2156-2164.

Giami, S., \& Bekeham, D. (1992). Proximate composition and functional properties of raw and processed full fat fluted pumpkin (Telferia occidentalis) seed flour. 
Journal of the Science of Food and Agriculture, 32. https://doi.org/10.1002/jfa. 2740590308

ljarotimi, O., \& Keshinro, O. (2012a). Formulation and nutritional quality of infant formula produced from germinated popcorn, Bambara groundnut and African locust bean flour. Journal of Microbiology, Biotechnology and Food Sciences, 2, 1358-1388.

Ijarotimi, O. S., Fagbemi, T. N., \& Osundahunsi, O. F. (2015). Determination of chemical composition, nutritional quality and anti-diabetic potential of raw, blanched and fermented wonderful kola (Bucholzia coriacea) seed flour. Journal of Human Nutrition and Food Science, 3(2), 1060.

ljarotimi, S., \& Keshinro, O. (2013). Determination of nutrient composition and protein quality of potential complementary foods formulated from the combination of fermented popcorn, African locust and Bambara groundnut seed flour. Polish Journal of Food and Nutrition Science, 155-166. https://doi. org/10.2478/v10222-012-0079-z.

ljarotimi, S. O., \& Keshinro, O. O. (2012b). Protein quality, hematological properties and nutritional status of albino rats fed complementary foods with fermented popcorn, African locust bean, and Bambara groundnut flour blends. Nutrition Research and Practice, 6(5), 381-388. https://doi.org/10.4162/ nrp.2012.6.5.381.

Ikujenlola, A. V., \& Ogunba, B. O. (2018). Potential complementary food from quality protein maize (Zea mays L.) supplemented with sesame (Sesamum indicum) and mushroom (Oudemansiella radicata). Journal of Nutrition \& Food Sciences, 8(3), 1-7.

Jachmanian, I., Perifanova-Nemska, M., Grompone, M., \& Mukherjee, K. (1995). Germinating rapeseed as biocatalyst: Hydrolysis of exogenous and endogenous triacyglycerols. Journal of Agriculture \& Food Chemistry, 43, 27893000.

Krishna-Motukuri, S. R. (2019). In A. Hossain (Ed.), Quality protein maize: An alternative food to mitigate protein deficiency in developing countries, maize production and use, (pp. 45-72). Rijeka: Intech open. https://doi.org/10.5772/ intechopen.89038.

Lamb, G. N. (1981). Manual of veterinary laboratory techniques, (pp. 70-71). Kenya: CIBA-GEIGY.

Landry, J., \& Delhaye, S. (1992). Simplified procedure for the determination of tryptophan of foods and feedstuffs from barylic hydrolysis. Journal of Agriculture \& Food Chemistry, 40, 776-779.

Malomo, S. A., Nwachukwu, I. D., Girgih, A. T., Idowu, A. O., Aluko, R. E., \& Fagbemi, T. N. (2020). Antioxidant and renin-angiotensin system (RAS) inhibitory properties of cashew nut and fluted-pumpkin protein hydrolysates. Polish Journal of Food and Nutrition Science, 70(3), 275-289. https://doi.org/10 31883/pjfns/122460.

Marero, L., Pajumo, E., \& Librando, E. (1988). Technology of weaning food formulation prepared from germinated cereals and legumes. Journal of Food Science, 1391-1395. https://doi.org/10.1111/j.1365-2621.1988.tb09284.x.

Mares, L. F. D. M., Passos, M. C., \& Menezes, C. C. (2018). Interference of germination time on chemical composition and antioxidant capacity of white sesame (Sesamum indicum). Food Science and Technology, 38, 248-253.

Mashood, S. B., \& Rizwana, B. (2010). Nutritional and functional properties of some promising legumes protein isolates. Pakistan Journal of Nutrition, 9(4), 373-379. https://doi.org/10.3923/pjn.2010.373.379.

Motuma, A., Azeb, L., \& Bekeso, G. (2016). Complementary feeding: Review of recommendations, feeding practices, and adequacy of homemade complementary food preparations in developing countries - Lessons from Ethiopia. Frontiers in Nutrition, 3-41. https://doi.org/10.3389/fnut. 2016.00041.

National Research Council, NRC (2009). Recommended dietary allowances, (10th ed., p. 230). Washington, DC: National Academic Press.

Obatolu, V., \& Cole, A. (2000). Functional property of complementary blends of soybean and cowpea with malted or unmalted maize. Food Chemistry, 147153. https://doi.org/10.1016/S0308-8146(99)00248-4.

Odebode, F. D., Ekeleme, O. T., ljarotimi, O. S., Malomo, S. A., Idowu, A. O., Badejo, A. A., ... Fagbemi, T. N. (2017). Nutritional composition, antidiabetic and antilipidemic potentials of flour blends made from unripe plantain, soybean cake and rice bran. Journal of Food Biochemistry, e12447, 1-9. https://doi.org/ 10.1111/jfbc.12447.

Ogunlade, I., Olaofe, O., \& Fadare, T. (2005). Chemical composition, amino acids and functional properties of selected seafood. Journal of Food, Agriculture and Environment, 130-133. https://doi.org/10.1234/4.2005.587.
Olagunju, A., \& Ifesan, B. (2013). Nutritional composition and acceptability of cookies made from wheat flour and germinated sesame (Sesamum indicum) flour blends. Current Journal of Applied Science and Technology, 32, 702-713.

Olapade, A. A., \& Aworh, O. C. (2012). Chemical and nutritional evaluation of extruded complementary foods from blends of Fonio (Digitaria exilis Stapf) and cowpea (Vigna unguiculata L. Walp) flours. International Journal of Food and Nutrition Science, 1(3), 1-8.

Omueti, O., Jaiyeola, O., Otegbayo, B., Ajomale, K., \& Afolabi, O. (2009). Development and quality evaluation of low-cost, high-protein weaning food types: Prowena and Propalm from soybean (Glycine max), groundnut (Arachis hypogea) and crayfish (Macrobrachium spp). Britannica Food Journal, 196-204. https://doi.org/10.1108/00070700910932002.

Onabanjo, O., Oguntona, C., Maziya-Dixon, B., Olayiwola, l., Oguntona, E., \& Dixon, A. (2008). Nutritional evaluation of four optimized cassava-based complementary foods. African Journal of Food Science, 2, 136-142.

Onyango, A., Borghi, E., de Onis, M., Casanovas, M., \& Garza, C. (2014). Complementary feeding and attained linear growth among 6-23-month-old children. Public Health Nutrition, 1975-1983. https://doi.org/10.1017/ S1368980013002401.

Osundahunsi, O., \& Aworh, O. (2003). A preliminary study on the use of tempeh based formula as a weaning diets in Nigeria. Journal of Plant foods for Human Nutrition, 58, 365-376.

Osundahunsi, O. F., Fagbemi, T. N., Kesselman, E., \& Shimoni, E. (2003). Comparison of the physicochemical properties and pasting characteristics of flour and starch from red and white sweet potato cultivars. Journal of Agriculture \& Food Chemistry, 2232-2236. https://doi.org/10.1021/ff0260139.

Palacios, O. M., Maki, K. C., Xiao, D., Wilcox, M. L., Dicklin, M. R., Kramer, M., .. Edirisinghe, I. (2020). Effects of consuming almonds on insulin sensitivity and other Cardiometabolic health markers in adults with Prediabetes. Journal of the American College of Nutrition, 39(5), 397-406.

Parsons, L., Ren, Y., Yobi, A., Hurst, P., Angelovici, R., Rodriguez, O., \& Holding, D. R. (2020). Production and selection of quality protein popcorn hybrids using a novel ranking system and combining ability estimates. Frontiers in Plant Science, 11, 698.

Poggiogalle, E., Fontana, M., Giusti, A. M., Pinto, A., lannucci, G., Lenzi, A., \& Donini, L. M. (2019). Amino acids and hypertension in adults. Nutrients, 11, 14591468. https://doi.org/10.3390/nu1107145.

Reeds, P., \& Garlick, P. (2003). Protein and amino acid requirements and the composition of complementary foods. Journal of Nutrition, 2953S-2961S. https://doi.org/10.1093/jn/133.9.2953S.

Semidei, R., da Cunha, F. C., de Souza, R. S., Macedo, M. L. R., Hiane, P. A., Rafacho, B. P. M., \& Sanches, F. F. Z. (2020). Protein supplement obtained from almonds of Bacuri fruit (Attalea phalerata Mart. Ex Spreng.): Elaboration, nutritional characterization and sensory acceptability. International Journal for Innovation Education and Research, 8(1), 232-247.

Shakerardekani, A., Karim, R., Ghazali, H., \& Chin, N. (2013). Textural, rheological and sensory properties and oxidative stability of nut spreads-A review. International Journal of Molecular Sciences. https://doi.org/10.3390/ ijms 14024223 .

Sofi, P., Wani, S., Rather, A., \& Wani, S. (2009). Quality protein maize (QPM): Genetic manipulation for the nutritional fortification of maize. Journal of Plant Breeding and Crop Science, 244-253. https://doi.org/10.5897/JPBCS.

Tan, S., \& Mattes, R. (2013). Appetitive, dietary and health effects of almonds consumed with meals or as snacks: A randomized, controlled trial. European Journal of Clinical Nutrition, 1-8. https://doi.org/10.1038/ejcn.2013.184.

Tufa, M., Urga, K., Weledesemayat, G., \& Mitiku, B. (2016). Development and nutritional assessment of complementary foods from fermented cereals and soybean. Journal of Food Science and Nutrition, 2, 1-8.

Udoh, E., \& Amodu, O. (2016). Complementary feeding practices among mothers and nutritional status of infants in Akpabuyo area, Cross River state, Nigeria. Springplus, 2073. https://doi.org/10.1186/s40064-016-3751-7.

United States Department of Agriculture, USDA (2018). USDA National Nutrient Database for standard reference https://www.ars.usda.gov/northeast-area/ beltsville-mdbhnrc/beltsville-human-nutrition-research-center/nutrient-datalaboratory/docs/usdanational-nutrient-database-for-standard-reference/

Wang, J. C., \& Kinsella, J. E. (1976). Functional properties of novel proteins: Alfafa leaf protein. Journal of Food Science, 41(2), 286-292.

\section{Publisher's Note}

Springer Nature remains neutral with regard to jurisdictional claims in published maps and institutional affiliations. 